\title{
Message in a bottle
}

\author{
The oceans have long accumulated the waste products of civilization. Dumping at sea is banned, but to \\ protect the marine environment we must also monitor litter on coastal lands and rivers.
}

When first setting their eyes on the $7 \mathrm{~km}$ deep Cayman Trough in the Caribbean Sea in February 2013, Jon Copley and his colleagues discovered that, poignantly, a beer bottle had got there first ${ }^{1}$. That beer bottle is not alone. Human-made rubbish has been found in the world's most remote oceans - and there is more and more of it. For example, repeated photographic analyses of the sea floor at Fram Straight ${ }^{2}$, the deepest entrance to the Arctic Ocean, showed that the amount of litter there doubled between 2002 and 2011.

Expanding shipping routes and more seaborne traffic could be partly to blame for the large volumes of discarded human products, such as ship paint and fishing equipment, in remote places. Furthermore, locations at high northern latitudes such as Fram Strait are affected by climate warming, another human impact: receding sea ice opens new paths for human-made debris into the deep sea.

Like so many pollution issues, the problem of rubbish in the ocean goes back, at least, to the industrial revolution. During the eighteenth century, when ships were mostly powered by steam, coal-fire waste - a hard, gritty substance known as clinker - was routinely disposed of overboard ${ }^{3}$. The clinker accumulated, and altered the sea bed. It now forms a hard, cobbled surface, whose distribution mirrors the ancient shipping routes on the sea floor.

At the time, ocean life below a depth of 300 metres was widely believed to be minimal or non-existent, and the deep ocean seemed to be an ideal dumping ground. We have since then learned that, instead, the deep oceans are full of life $\mathrm{f}^{4}$ and that they represent a sensitive and vital component of the whole Earth system.

Clinker on the sea bed has even been mapped as a recognisable rock unit ${ }^{5}$. Such a human-made strata is one piece in the jigsaw supporting the contention that the Anthropocene should be viewed as a distinct period in time ${ }^{6}$. The clinker layer also exposes the fact that human activities permanently change the landscape - on the sea floor as well as on land.

Today, litter in the oceans is mostly composed of plastic, not coal. International agreements that banned the disposal of waste at sea were imposed only in 1988.

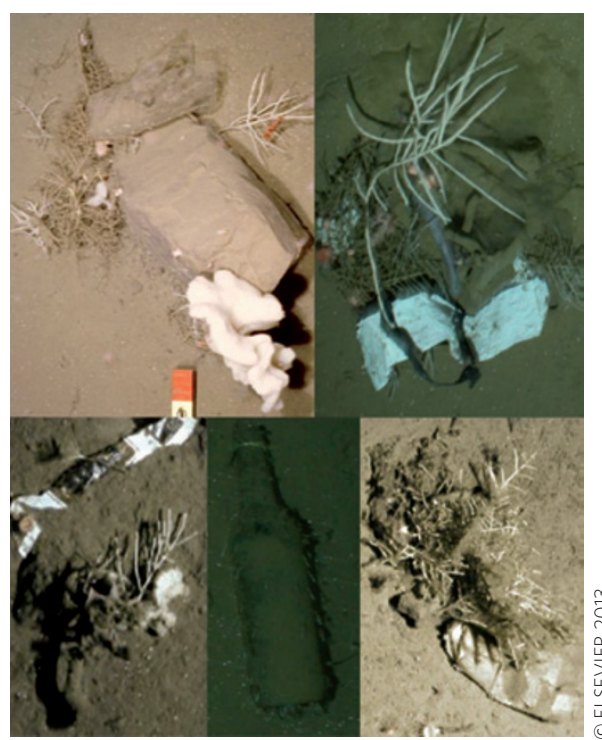

dubbed the Great Pacific Garbage Patch. The amount of debris within the patch is largely unknown, with estimates varying by several orders of magnitude. The exact size of the patch, too, is unknown because it is mostly composed of micro-plastics that float just below the water surface, so cannot be easily detected by satellite observations.

Just like whales swallow whole flower pots, fish and microorganisms mistake the tiny micro-plastic fragments for food. The particles thus enter the food chain, and may eventually even be incorporated into the cells of organisms ${ }^{12}$. Micro-plastics are usually thought not to react chemically with other substances, but evidence on how they might behave in the body or whether they can react with other chemicals to become toxic is scarce.

The direct disposal of waste into the seas has been banned, but human-made substances still make their way into the oceans in large amounts. It is clearly not enough to forbid dumping only in the high seas. One way forward could be to retrieve plastic waste from the sea and sea-shore by setting up partnerships with fishermen to gather the litter ${ }^{13}$. The waste could then potentially even be recycled and turned into something useful - although, really, enough litter to make the scheme worthwhile should never have entered the sea in the first place.

Perhaps there is a message in that bottle in the Cayman Trough: rubbish blowing around on coastal lands and floating in rivers must be drastically reduced if we are to protect the oceans and marine life. It is time to impose tighter regulations.

\footnotetext{
References

1. http://www.thesearethevoyages.net/jc82/feb13.html

2. Bergmann, M. \& Klages, M. Mar. Pollut. Bull. 64, 2734-2741 (2012).

3. Ramirez-Llodra, E. et al. PLoS ONE 6, e22588 (2011).

4. Glud, R. N. et al. Nature Geosci. 6, 284-288 (2013).

5. Kidd, R. B. \& Huggett, Q. J. Oceanol. Acta 4, 99-104 (1981).

6. Zalasiewicz, J. Nature Geosci. 6, 8-9 (2013).

7. O'Brine, T. \& Thompson, R. C. Mar. Pollut. Bull. 60, 2279-2283 (2010).

8. Gross, M. Curr. Biol. 23, R135-R137 (2013).

9. De Stephanis, R., Giménez, J., Carpinelli, E., Gutierrez-Exposito, C. \& Cañadas, A. Mar. Pollut. Bull. http://dx.doi.org/10.1016/j. marpolbul.2013.01.033 (2013).

10. Day, R. H., Shaw, D. G. \& Ignell, S. E. in.Proc. Second Intl Conf. Marine Debris (eds Shomura, R. S. \& Godfrey, M. L.) 247-266 (US Dept. Commerce, 1990).

11. Moore, C. Natural History Magazine 112, n9 (2003).

12. Rochman, C. M. \& Browne, M. A. Nature 494, 169-171 (2013).

13. http://www.guardian.co.uk/environment/2013/mar/07/ecoversea-plastic-bottles-recycling/
} 